\title{
SPATIALAND TEMPORAL DISTRIBUTION OFA TIGER BEETLE GUILD (COLEOPTERA: CARABIDAE: CICINDELINAE) ALONG A 105m LONG TRANSECT IN THE RESERVA FLORESTAL A. DUCKE NEAR MANAUS (CENTRAL AMAZONIA)
}

\author{
Wilfried PAARMANN', Joachim ADIS ${ }^{2}$, Kirsten LÜDECKE', Nicole \\ TOBASCHUS ${ }^{1}$, Claudio R.V. da FONSECA ${ }^{3}$
}

\begin{abstract}
The spatial and temporal distribution of a guild of eight diurnal tiger beetle species was studied on a $105 \mathrm{~m}$ long transect near the field station of the Reserva Florestal A. Ducke near Manaus (AM), Brazil. The transect followed a path that included both shaded and an open areas. Five of the species, restricted to primary forest, occurrred only in shaded areas of the transect, and three species occurred in open areas. Of all eight species only two of the open habitat species showed no clear seasonality in adult activity. In six species the activity of adults was limited to the rainy season. The most pronounced annual rhythm was found in Pentacomia ventralis, an open habitat species. Activity of adults was limited to October/November. First instar larvae appeared shortly thereafter. Larval development mainly took place from January to May. The third instar larva entered a dormancy which lasted up to 10 months, and which enabled the synchronisation of emerging adults with annual seasons.
\end{abstract}

Key words: Tiger beetles, guild structure, terra firme, Amazon.

Distribuição Espacial e Temporal de uma Associação de Cicindelídeos (Coleoptera: Carabidae: Cicindelinae) ao Longo de um Transecto de $105 \mathrm{~m}$ na Reserva Florestal A. Ducke Perto de Manaus (Amazônia Central).

RESUMO - A distribuição espacial e temporal de uma associação de cicindelídeos diurnos foi estudada num transecto de $105 \mathrm{~m}$ próximo à estação de campo da Reserva Florestal A. Ducke, perto de Manaus (AM), Brasil. O transecto seguiu uma trilha, incluindo áreas sombrias e ensolaradas. Cinco das espécies, restritas à floresta primária, ocorreram somente nas áreas sombrias do transecto, e três espécies ocorreram em áreas abertas. Das oito espécies, somente duas, dos habitats abertos, nẫo mostraram uma distinta atividade sazonal. Em seis espécies, a atividade foi restrita à epoca de chuva. O ritmo anual mais pronunciado foi constatado para Pentacomia ventralis, uma espécie de habitats abertos. A atividade de adultos foi limitada a Outubro/Novembro. Larvas do primeiro estádio apareceram logo em seguida. O principal desenvolvimento larval foi de Janeiro até Maio. A larva do terceiro estádio entrou em dormência, com uma duração de até 10 meses, possibilitando assim a sincronizaçâo da eclosão dos adultos com as estações do ano.

Palavras-chave: Cicindelideos, estrutura de associação, terra firme, Amazônia.

\section{INTRODUCTION}

Pearson \& Mury (1979) found that the median prey size for tiger beetle species tested was directly correlated with mandible size. Different mandible sizes in species of a cicindelid guild may therefore minimize interspecific competition resulting in a pattern of limiting similarity (Hutchinson ratios) for co-occurring species. Studying tiger beetle communities from 10 primary forests sites in

\footnotetext{
Fachhochschule Hildesheim/Holzminden, Fachbereich Forstwirtschaft und Umweltmangement, Büsgenweg 1A, D-37077 Göttingen, Germany.

2 Max-Planck-Institut für Limnologie, AG Tropenökologie, Postfach 165, D-24302 Plön, Germany.

3. Instituto Nacional de Pesquisas da Amazônia (INPA), CPEN, Caixa Postal 478, 69011-970 Manaus/ AM, Brazil.
} 
the New and Old World tropics, Pearson (1980) found that at all sites the mandible length for a species and each of its most similar-sized congener was generally greater than 1.35 . These findings support the idea that the structure of a tiger beetle guild is the result of limiting similarities by competition for prey (discussed also in Pearson (1988) and Pearson \& Knisley (1985), but see Pearson \& Juliano (1991)).

On the floor of non-flooded upland forest (terra firme) of the Forest Reserve A. Ducke near Manaus (Amazonia) we found a community of 6 tiger beetle species. Pearson (1980) found only two out of ten sites, where a maximum of 5 species coexisted on the forest floor. We decided to study this community as an example of the deterministic principle (high species diversity by dense packing due to strong niche separation; Linsenmair, 1990) during the program "Mechanisms that maintain tropical diversity" (German Research Foundation). The highest diversity of tiger beetle species in our study site was found around the field station (see Fig. 2 in Adis et al., 1998). Along a $105 \mathrm{~m}$ long transect, following a path that connected the field station with the meteorological station, we found 8 common terrestrial species, all showing a similar foraging behavior. In one species (Pentacomia ventralis) we detected great numbers of larvae on and close to the path. This offered an opportunity to study the spatial and temporal distribution of all species and to collect life history data of one of them.

\section{MATERIAL AND METHODS}

\section{Study site}

The Reserva Florestal Adolpho Ducke is located about $26 \mathrm{~km}$ north-east of Manaus ( $\left.2^{\circ} 55^{\prime} \mathrm{S}, 59^{\circ} 59^{\prime} \mathrm{W}\right)$. It belongs to the National Institute for Amazonian Research (INPA) in Manaus, Brazil.

The observed path between the field station and the meteorological station was $115 \mathrm{~m}$ long and about $1.5 \mathrm{~m}$ wide. We divided $105 \mathrm{~m}$ of this path into seven segments of $15 \mathrm{~m}$ each: segments $1-4$ were shaded by the crowns of some planted trees (Carapa guianensis, Meliaceae) and secondary forest tree species of the genera Bellucia, Loreya, Miconia, Vismia (see Fig. 1). Segments 5-7 were open, with a shrub like vegetation on one side and bare latosol on the other side. Figure 2 shows the transition zone between shaded and open parts of the trail.

\section{Climate}

The year is divided into a rainy season (December-May: average precipitation $1550 \mathrm{~mm}$ ) and a "dry season" (June-November: average precipitation $550 \mathrm{~mm}$ ), but each month has significant precipitation; see Ribeiro \& Adis, 1984; Ribeiro \& Villa NovA, 1979). Nine years of precipitation records are available for Reserva Ducke (Fig. 13; data from Ribeiro \& Villa Nova, 1979).

In 1994, at the Reserva Florestal A. Ducke: Mean annual maximum temperature was $31.4^{\circ} \mathrm{C}$ (range $29.4-33.2^{\circ} \mathrm{C}$ ); mean annual minimum temperature was $22.1^{\circ} \mathrm{C}$ (range $21.4-22.6^{\circ} \mathrm{C}$ ); and mean annual temperature amplitude was 


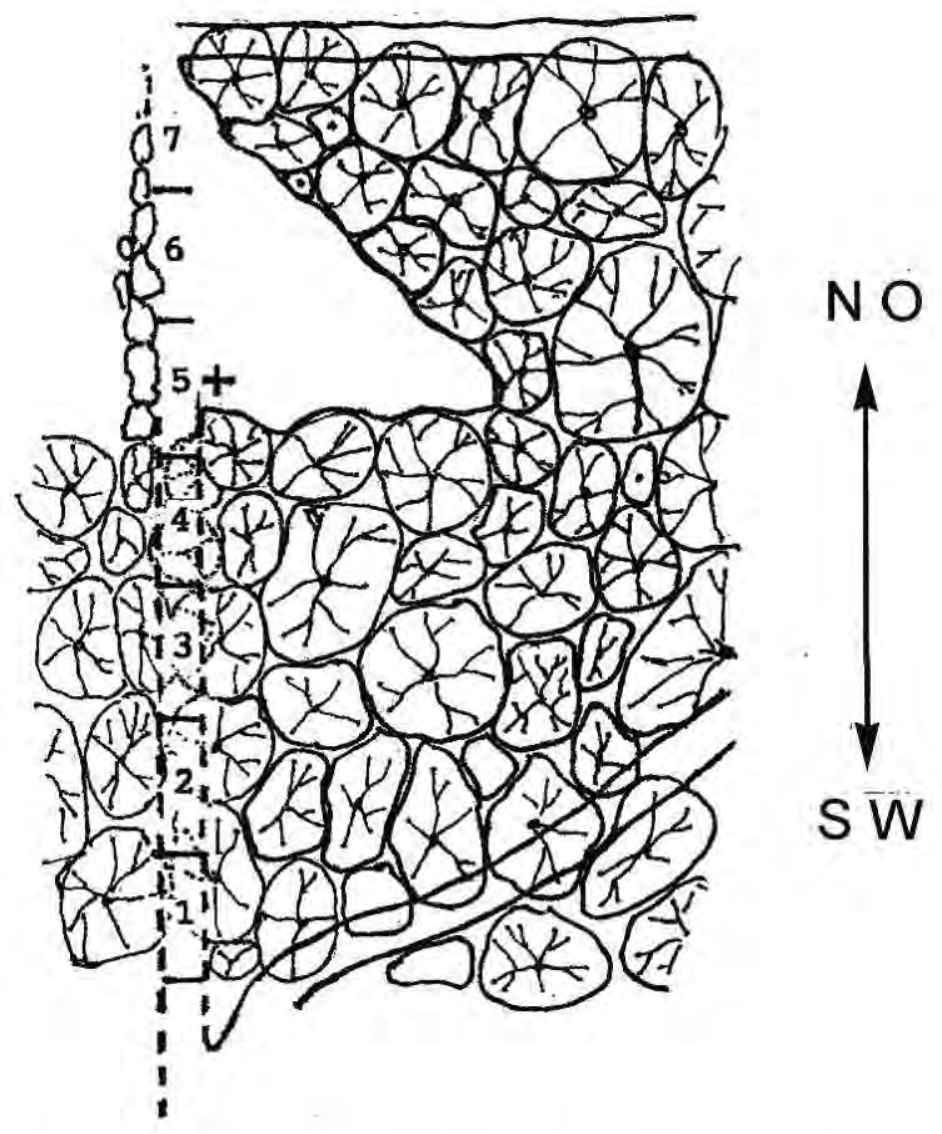

Figure 1. Sketch of the study site. $1-7=$ segments on the transect of $15 \mathrm{~m}$ each: $1-5$ shaded, 5 7 open; $+=$ larval study site.

$9.3^{\circ} \mathrm{C}$, highest in August with $11.4^{\circ} \mathrm{C}$ and lowest in January with $7.1^{\circ} \mathrm{C}$.

\section{The tiger beetle species observed}

Four diurnal species of the genus Odontocheila $(O$, cayennensis (Fab), $O$. chrysis (Fab), O. luridipes (Dejean) and $O$. margineguttata (Dejean)) two diurnal species of the genus Pentacomia $(P$. lacordairei Gory and $P$. ventralis (Dejean), and one species each of the genera Cenothyla and Brasiliella $(C$. varians (Gory), B. argentata $(\mathrm{F})$.$) were$ common on the transect path.

The following natural history data are available for each species (Pearson, 1984; Rodrigues et al; 1994; Pearson \& Huber, 1995): O. chrysis, $O$ margineguttata, $P$. lacordairei, $P$. ventralis and $B$. argentata have a broad distributional range from Venezuela to northem Argentina or northern Bolivia. $O$. cayennensis, $O$. luridipes and $C$. varians have a more restricted distribu- 
tion in Amazonian South America. $O$. cayennensis, $O$. luridipes, $C$. varians and $P$. lacordairei occur on the floor of primary forest (terra firme), but $P$. lacordairei also occurs on the floor of floodplain forest. $O$. chrysis and $O$. margineguttata both occur in clearings, wide paths of secondary forest, although $O$. margineguttata can sometimes be found in primary forest. These two species are occasionally syntopic. $P$. ventralis is a species of grassy areas and extensively cleared forest patches. The $B$. argentata complex of similar species occurs generally in open upland areas, away from water (Freitag \& Bames, 1989).

\section{Studies on the spatial and temporal distribution of adults}

Once a month (March 94 to February 95) we captured and released all individuals we could see on the path by using an aerial net: we conducted this census for three successive days around the middle of the month, and each census day consisted of three walks up and down the transect path. Captured beetles were marked on the elytra with colour paint spots (different for each month) and before being released. The segment of the path in which each specimen was initially observed was noted. To distinguish the similar species $O$. chrysis and $O$. margineguttata we used a hand mag. nifying lense to recognize a distinctive dimple at the posteriolateral part of the pronotum in $O$. chrysis.

\section{Studies on larval appearance and development}

An area of $20 \mathrm{~m}^{2}$ of sparsely vegetated to bare latosol bordering the trail (Fig. 2) contained a high concentration of $P$. ventralis larval burrows. At weekly intervals the larval activity in this area was censured using absence or presence (head of larva visible

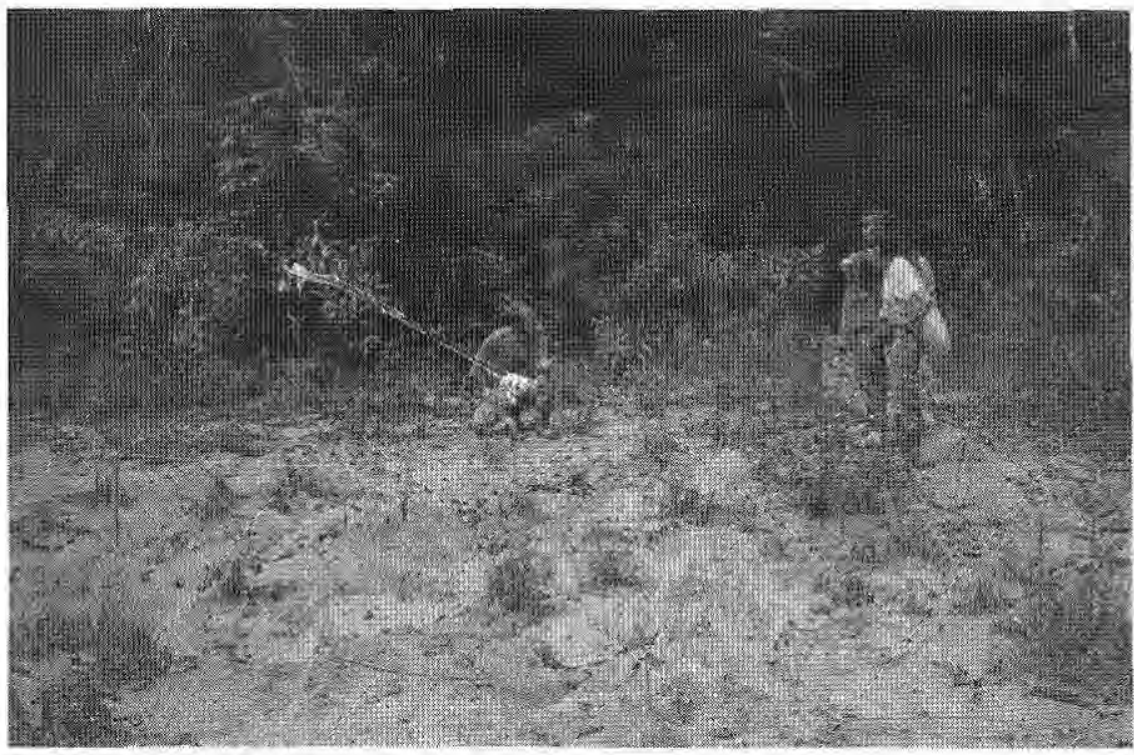

Figure 2. Photograph of the transition zone between segment 4 and 5 of the transect (first author at left in the fenced larval site). 
in the opening of its tunnel), larval instar (diameter of the opening) and the appearence of additional larvae. Each larval tunnel was marked with a small flag and a number. If the tunnel was open, no larva visible and the opening not cleaned, we extracted the larva. This study of larvae was conducted from February 1993 to August 1994. Morphological data are given in Arndt et al. (1996).

\section{Rearing and breeding in the laboratory}

To obtain additional information about the life history of $P$. ventralis we transferred larvae from Manaus to our laboratory in Göttingen (Germany). Here we placed individual larvae in glass tubes (heigth $7.5 \mathrm{~cm}$, diameter $2.8 \mathrm{~cm}$ ) filled with loam to a height of $5 \mathrm{~cm}$ and under a temperature regime of $25 / 27^{\circ} \mathrm{C}$ (15hs/9hs) and a $12 \mathrm{hs} / 12$ hs day/night photoperiod. Adults were kept in clear plastic containers (width $50-30 \mathrm{~cm}$, height $30 \mathrm{~cm}$ ) filled with loam to a height of $15 \mathrm{~cm}$. During daylight (12hs) the beetles could choose a prefered temperature under the radiation zone of a desk lamp. During night time they were exposed to $23^{\circ} \mathrm{C}$. As food for both larvae and adults we used Drosophila flies or small Tenebrio molitor larvae.

\section{RESULTS}

\section{Spatial distribution}

By habitat choice along the transect, the species can be divided into two groups: Adults of five species ( $C$. varians, $O$. cayennensis, $O$. luridipes, $O$. margineguttata, $P$. lacordairei) occurred primarily in the shaded part and thus represent forest interior species (Fig. 3); adults of three species ( $B$. argentata, $O$. chrysis, $P$. ventralis) occurred primarily in the open parts (Fig. 4; see Freitag \& Barnes, 1989).

Of the five forest interior species, only $O$. margineguttata also appeared regularly in open sites. Of the open habitat species, only $O$. chrysis appeared regularly in the shaded part. There is a transition zone (Fig. 5) in the path segments 4 and 5 where both species occurred together.

\section{Temporal distribution}

The group of forest interior species showed a strong and relatively synchronous change in seasonal abundance: High abundance of adults during the rainy season, low abundance during the dry season (Fig. 6). Among the open habitat species (Fig. 7), B. argentata showed no fluctuation of abundance correlated with annual seasons. The abundance of $O$. chrysis was continuously high throughout the year. $P$. ventralis showed a strong seasonal correlation of abundance that resembled changes in the population abundance of $O$. margineguttata (see Fig. 8 ). The adults appeared nearly exclusively during October and November.

\section{Larval development of $P$. ventralis in the field and under laboratory conditions}

Tunnels of the first and under laboratory conditions larval instar appeared mainly during December and January (Fig. 9), shortly after the disappearance of the adults. By February, larvae of the third instar appeared. From March to June the number of active lar- 

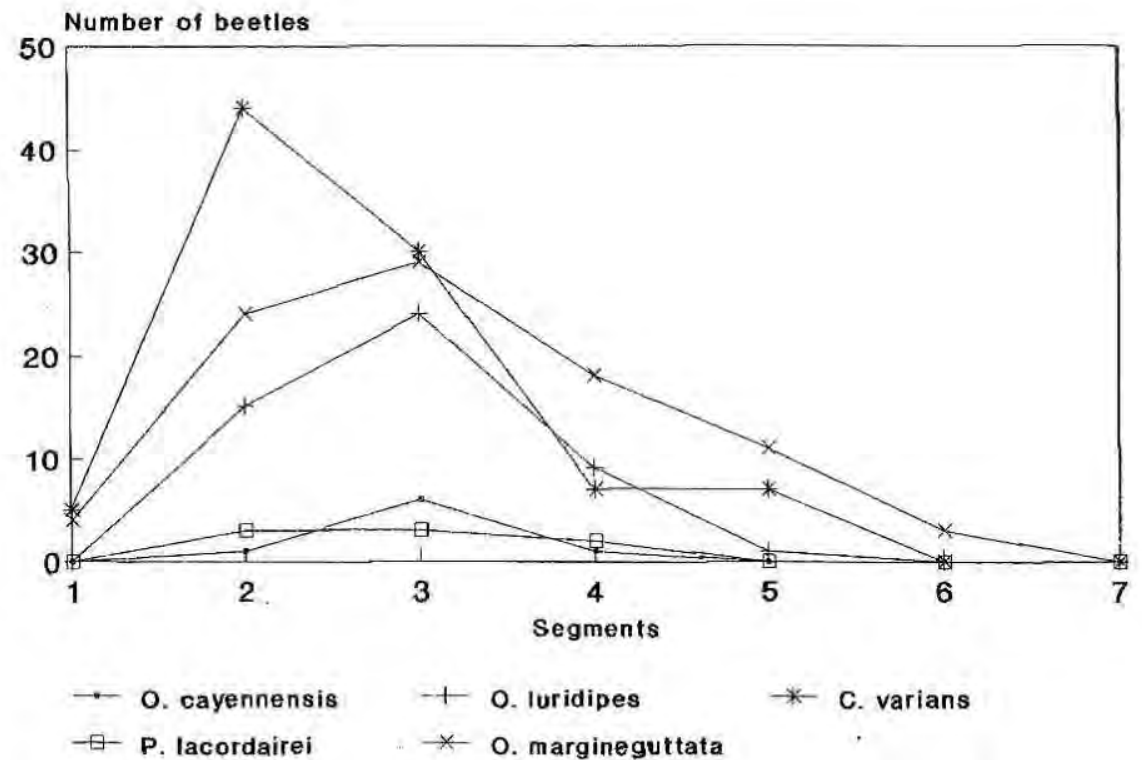

Figure 3. Spatial distribution of the forest interior species on the transect. Segments 1-4 shaded 5-7 open.

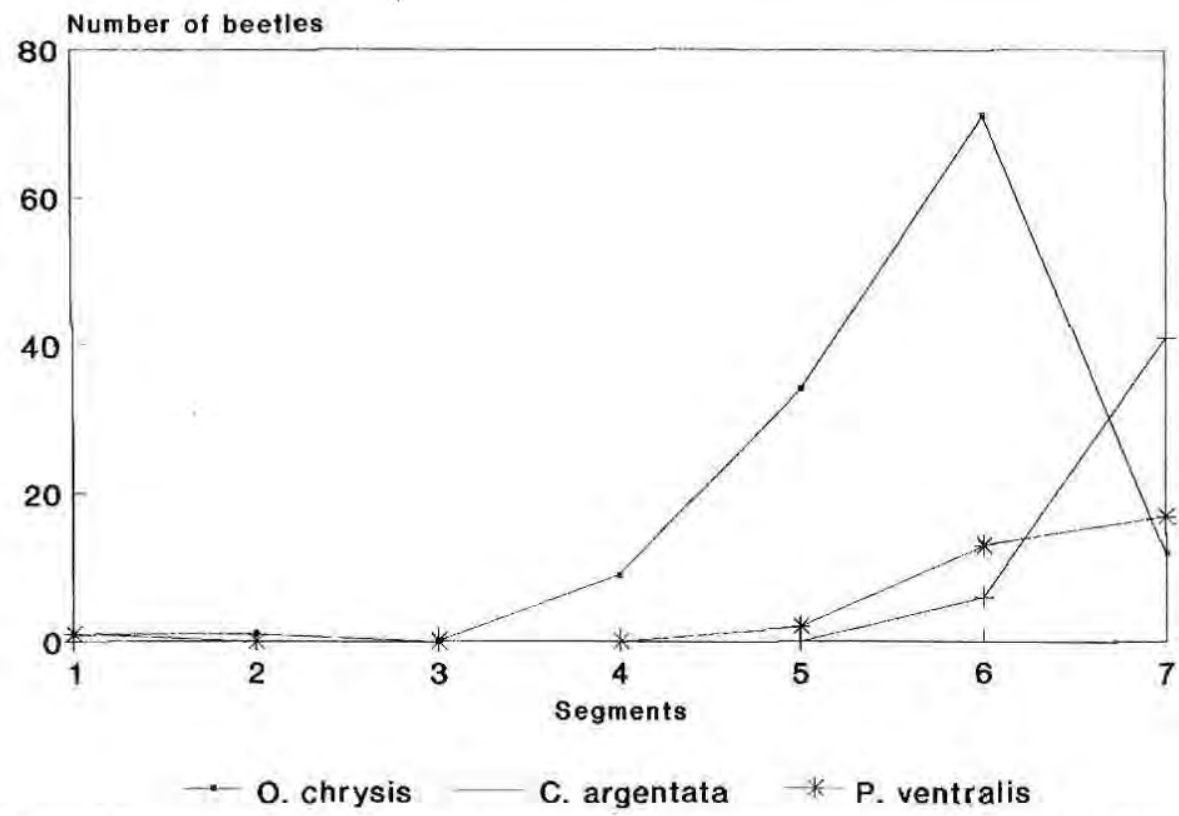

Figure 4. Spatial distribution of the open habitat species on the transect. Segment 1-4 shaded, 5-7 open. 


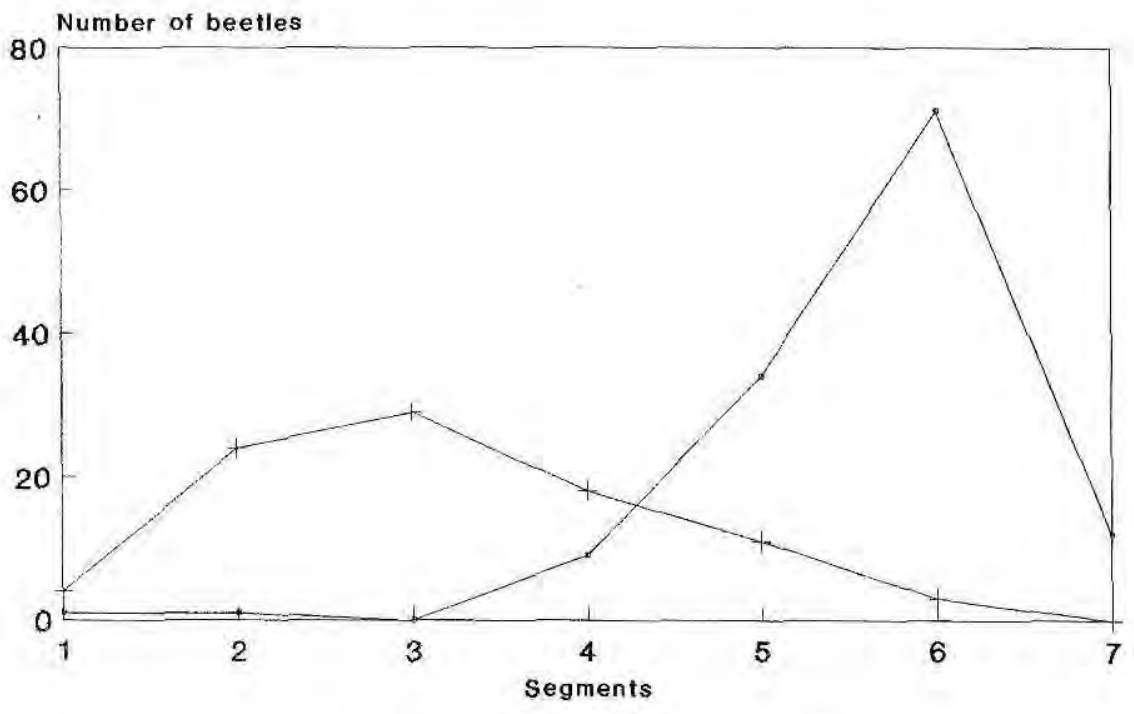

o. chrysis + C. margineguttata

Figure 5. Spatial distribution of $O$. chrysis and $O$. magineguttata on the transect. Segments 1-4 shaded, $5-7$ open.

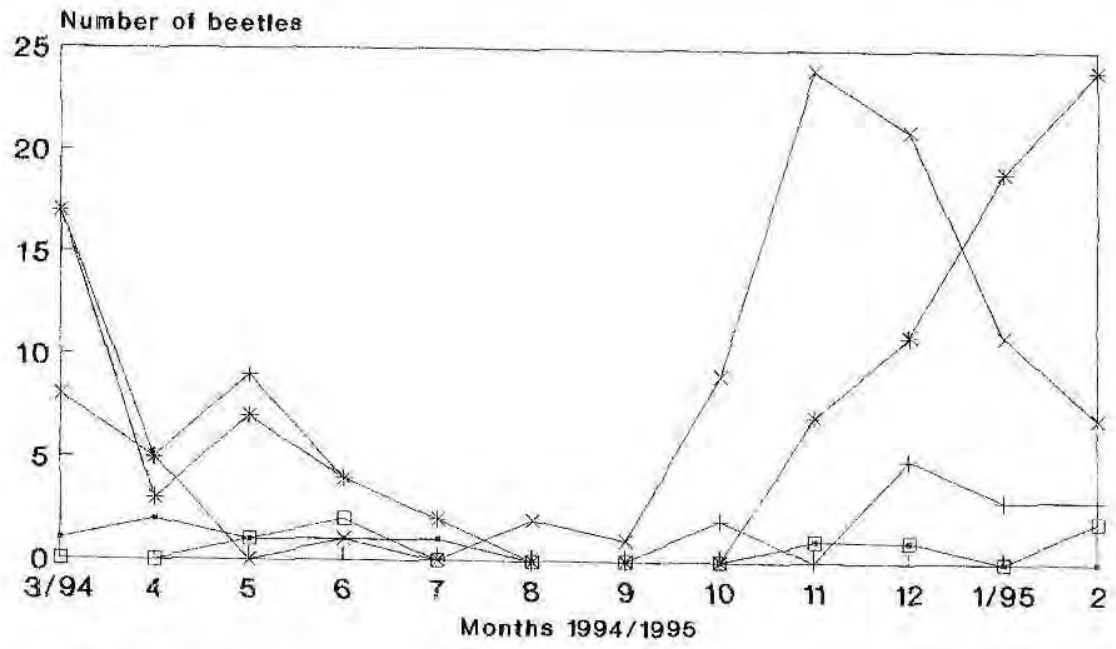
O. cayennensis
O. luridipes
$\rightarrow$ * C. varians
$\rightarrow$ P. lacordairei
O. margineguttata

Figure 6. Seasonal abundance of the five forest interior species. 


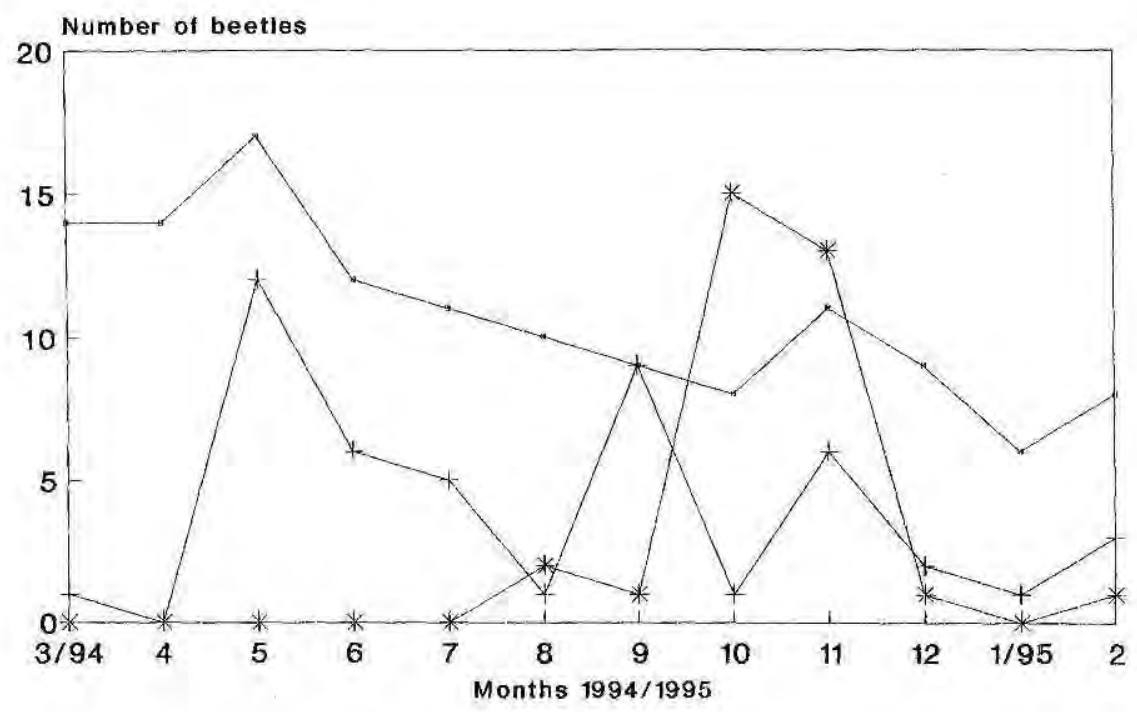

$\rightarrow$ o. chrysis $\quad-$ C. argentata $\quad *$ - P. ventralis

Figure 7. Seasonal abundance of the three open habitat species.

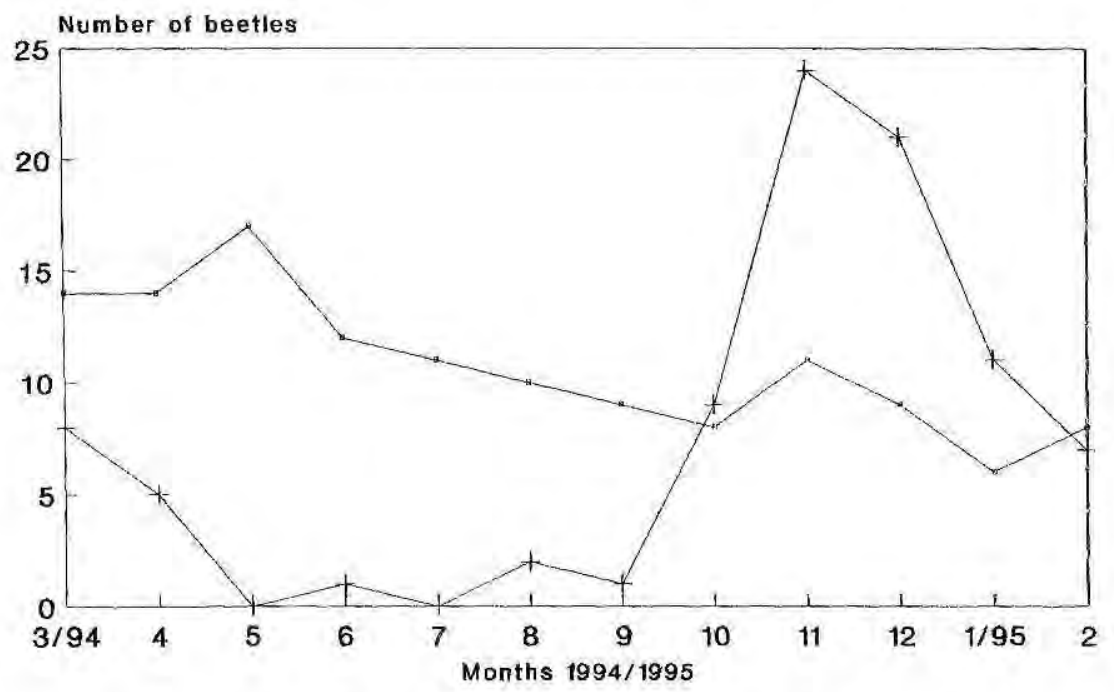

$\rightarrow$ - o. chrysis $\quad+0$. margineguttata

Figure 8. Seasonal abundance of $O$. chrysis and $O$, margineguttata. 


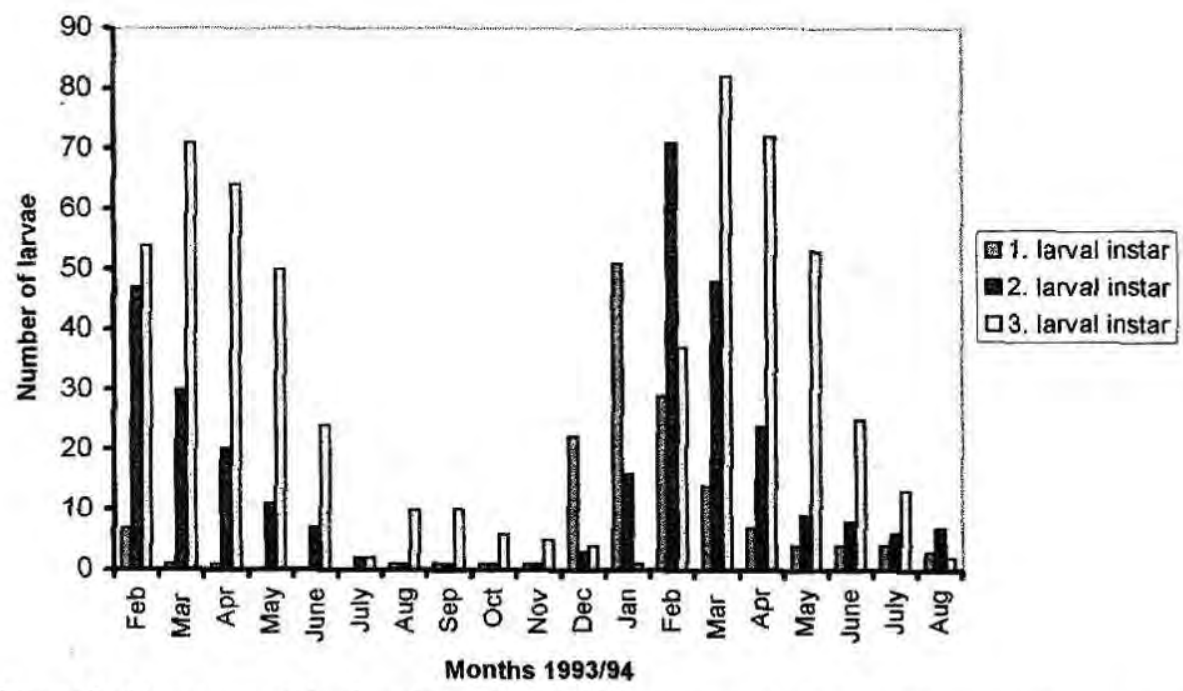

Figure 9. Abundance of the three larval instars of $P$. ventralis at the fenced larval study site $\left(20 \mathrm{~m}^{2}\right)$ from February 1993 to August 1994.

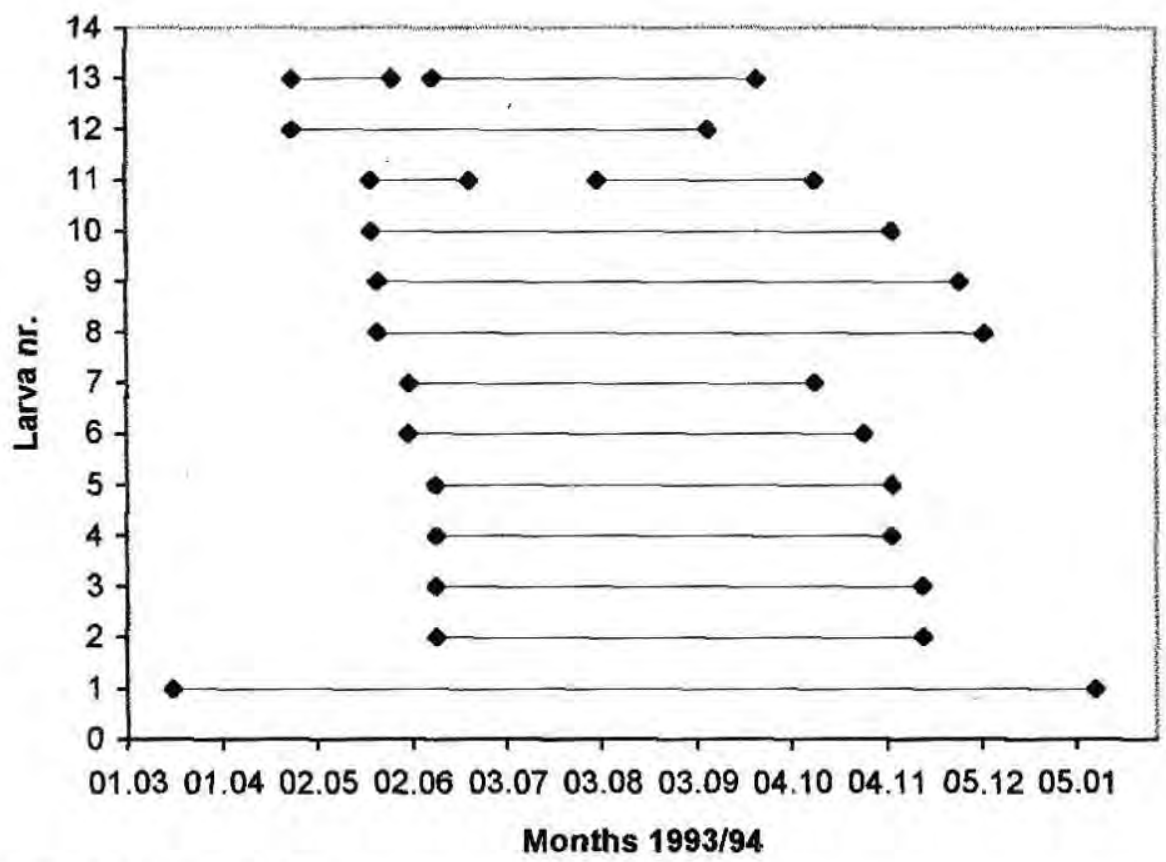

Figure 10. Duration of dormancy in last instar larvae $(\mathrm{n}=13)$ of $P$. ventralis at the study site, 


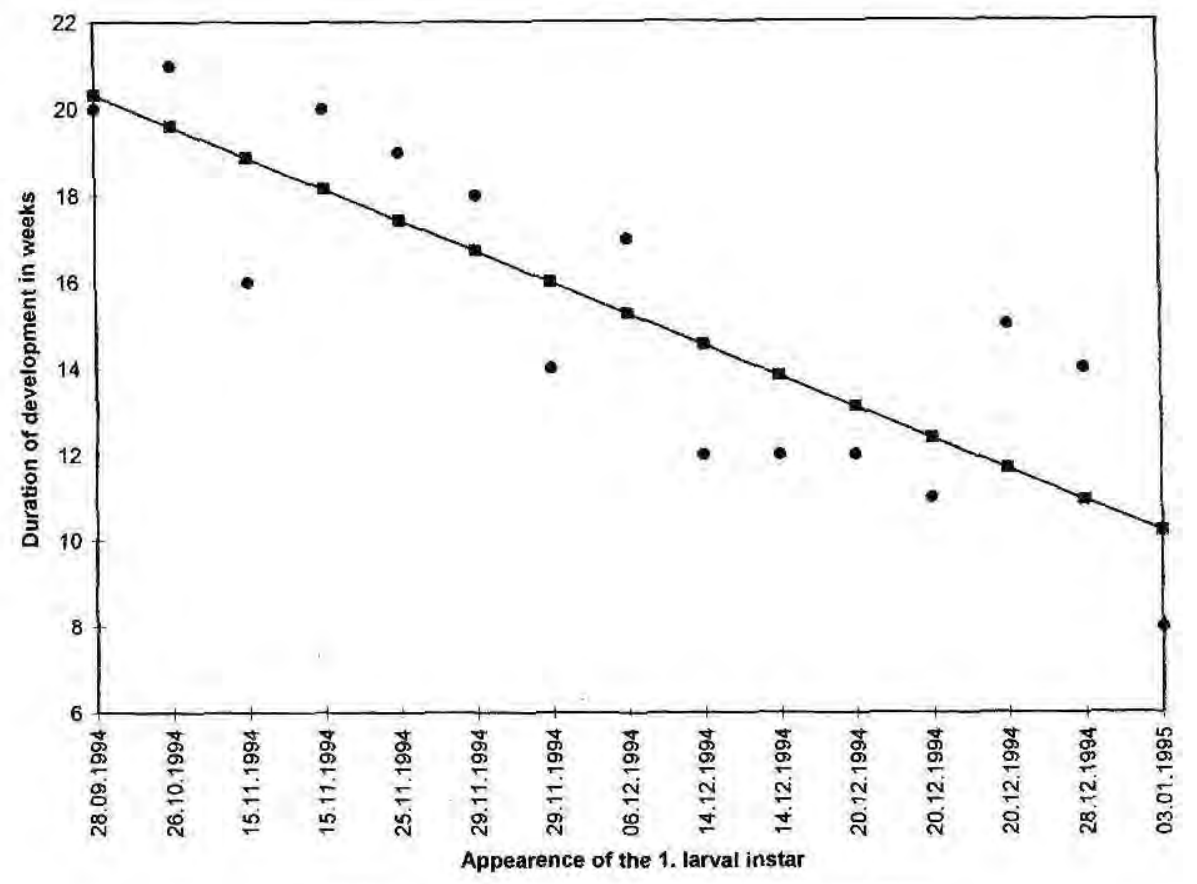

- Duration of development $\rightarrow$-linear regression

Figure 11. Correlation between the date of appearance of the first larval instar and the duration of its development to the third larval instar in $P$. ventralis $(y=-0.7 \mathrm{x}+20.38 ; \mathrm{p}<0.001, \mathrm{r}=-0.853 ; \mathrm{n}=12)$.

vae declined, and from July to November little to no active larvae were visible.

Apparently the larvae develop rapidly to reach their maximum size in the last (3rd) instar. Then they close their tunnel and stay in a larval dormancy until pupation. The longest time period between the last closing of the tunnel and the hatching of beetles under natural conditions was 10 months (Fig. 10). Only two of the observed 13 larvae interrupted their "dormancy" to open their tunnels again for a short period.

The later in the season (Oct.-Dec.) that the first larval instar appeared the shorter its potential time for development into the third larval instar (Fig. 11). This could indicate a better supply of prey for the younger larvae during December than during November.

Under laboratory conditions the pupal stage lasted 9 or 10 days $(n=2)$. The hatched beetles appeared 6 or 7 days $(n=2)$ after hatching on the soil surface. For the remaining 29 specimens we calculated the duration of larval dormancies by subtracting 17 days (i.e., pupal stage plus hatching period) from the time between the last closing of the tunnel and the appearance of the beetle. On average they remained 205 days (range: 81-349) in dormancy.

During dry season conditions in the laboratory, larvae tended to keep their tunnel closed directly after we watered the soil. This indicates that larval dormancy under dry soil condi- 
tions in nature may be longer than measured (the time between the last closing of the tunnel and the appearance of the beetle), as larvae may enter dormancy but have to wait for the next rain to close the tunnel opening.

Fifty-six percent of the larvae kept under laboratory conditions in Germany hatched within three successive months (Sept.-Nov.). Compared to data from the other months of the year, this difference was significant ( $\mathrm{Chi}^{2}$-test, $\mathrm{p}<0.01$ ). The hatching in the laboratory corresponded with the appearance of adults under natural conditions (Fig. 12).

Five adult beetles of $P$. ventralis, which adapted to the described laboratory conditons, lived about 3.5 months on the surface (plus 7 days in the soil after hatching). The average adult lifespan was 104 days (min: 88 days, max.: 113 days). The first copulation was observed 5 days after emergence.

\section{DISCUSSION}

From our results it is obvious that the species richness of tiger beetles found on the relatively short transect has been impacted by human intervention. In clearing part of the forest floor, open habitats were made which were invaded by species adapted to such conditions. Only one of the six species found in a nearby intact primary forest (O. nigrotarsalis) was not caught on our study transect. However this is the rarest of the forest interior species in the region.

Of the five forest species, $C$. varians, $O$. cayennensis, $O$. luridipes, and $P$. lacordairei have all been described from other parts of Amazonia as primary forest species, while $O$. margineguttata was described as a secondary forest species that entered primary forest edges only during the height of the rainy season (Pearson, 1984; Pearson \& Huber, 1995; Rodríguez et al., 1994). From other of our unpublished studies in a primary forest site (Paarmann et al., unpubl.), O. margineguttata generally uses microhabitats similar to those of the more typical primary forest species, but the adults tend to appear earlier, at the end of the dry season. They also do not avoid open habitats as consistently as the other forest interior species (Figs. 3, 6, 13, and unpubl. data). While the adult abundance of the true primary forest species $(C$. varians, $O$. cayennensis, $O$. luridipes, $P$. lacordairei) is closely correlated with the mean monthly rainfall $(\mathrm{y}=0.1 \mathrm{x}-8.85$; $\mathrm{p}<0.001, \mathrm{r}=+0.842 ; \mathrm{n}=12$; see also Fig. 13 ), the species $O$. margineguttata and $P$. ventralis appear mainly at the beginning of the rainy season (Fig. 13). Thus the larvae can develop throughout the rainy season and avoid impact of dryness. The seasonal change in adult abundance is confirmed for the forest species to be regularly by a five year study in a primary forest site. The results of this detailed study concerning seasonal abundance and niche separation will be published elsewhere.

O. chrysis showed a comparable high and constant abundance throughout the year. From the literature it is known that $O$. margineguttata and $O$. chrysis can occur sympatrically (Pearson, 1984; Pearson \& Huber, 1995). In our study site this sympatric appearance is limited to a small area at the forest border site (Fig. 5) and to the rainy season (Fig. 8). 


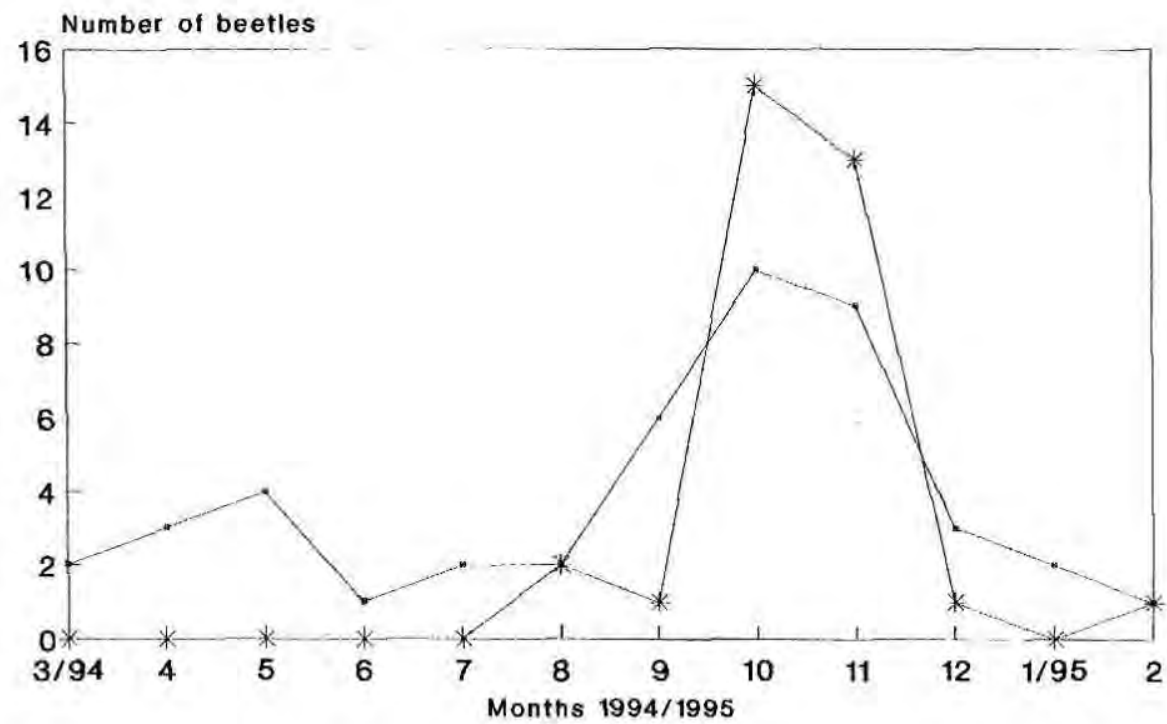

P. ventralís: lab * P. ventralis: nature

Figure 12. Appearance of adults in $P$. ventralis under natural conditions (Forest Reserve) and under laboratory conditions (Germany).
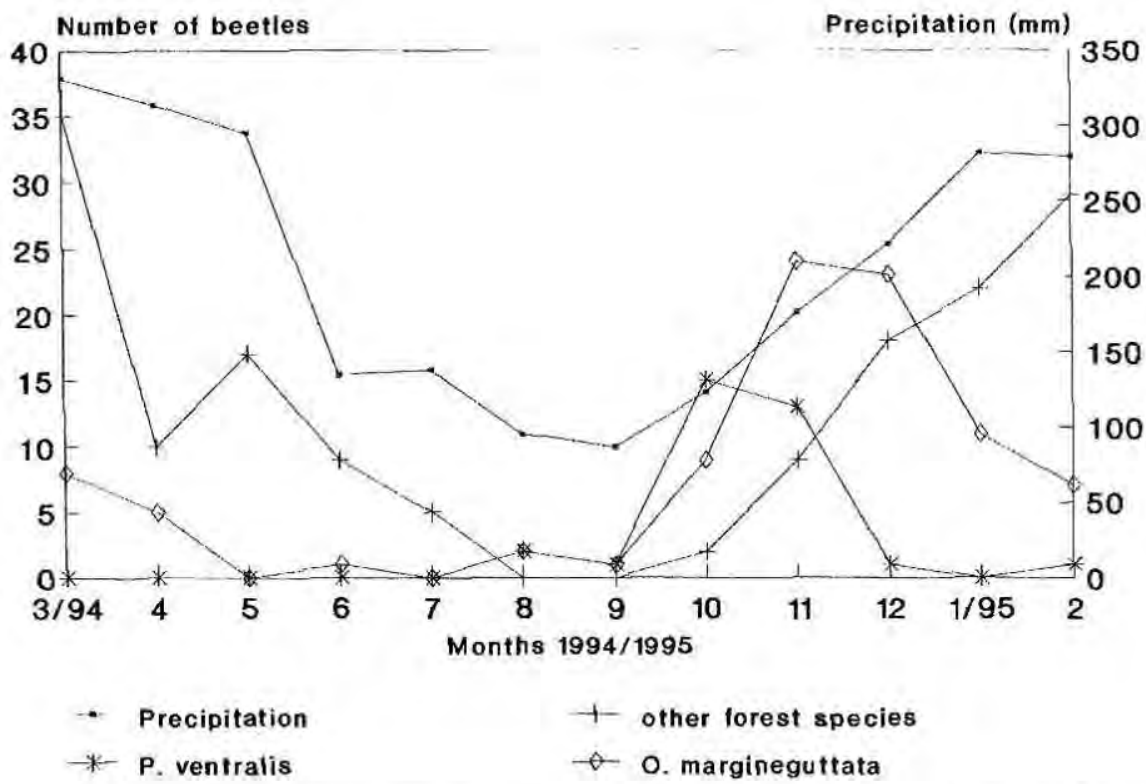

Figure 13. Mean monthly rainfall in the Reserva Florestal A. Ducke (from Ribeiro \& Vilailla Nova, 1979) and adult abundance of the seasonal tiger beetle species. 
The abundance of adult beetles of $B$. argentata (Fig. 7) fluctuated irregularly, independent of the season. This may be the result of migration between the three open sites in the field station area. A few larvae of this species were found along the path at the open site, more of them at the central open site of the field station area (see also Fig. 2 in Adis et al., 1998).

$P$ ventralis is described as a species of "extensively cleared forest sites" (Pearson, 1984; Rodríguez et al., 1994). The seasonal appearence of adults in this species resembles very much that of the forest species $O$. margineguttata, but is more pronounced (Fig. 13). It is limited to the months October and November. Under laboratory conditions we found an average life expectance in adults of 3.5 months $(n=5)$. This seems to be much shorter under natural conditions. But adults reach their sexual maturity few days after emergence. The larvae of the first instar were found shortly after the disappearance of adults, mainly during December and January (Fig. 9). The data summarized in figure 11 indicate that the conditions for the development of the first and second larval instar improve from November to December, probably even more in January. The strategy of this species seems to be a comparable rapid larval development leading to a larval dormancy in the third instar. This stage is spent in its closed tunnel for the suitable time of pupation (Fig. 10). The pupation may be caused by a combination of an endogenic component (clock system) and the signal of a climatic factor as "zeitgeber". The synchronous hatching of the beetles, also under laboratory conditions (Fig. 12), points to a strong endogenic con- trol. $P$. ventralis seems to be a strictly univoltine species. Asimilar life cycle was found in P. egregia (Paarmann et al., 1982) from the inundation forests near Manaus. However, in this species the synchronisation of life cycle with seasons is caused by a gonad dormancy in females which is induced by lower variations between the day and night temperatures due to flooding (Amorim et al., 1997a,b).

The strong seasonality in 6 out of the 8 observed species is presumably the result of selective forces caused by optimal or poor food conditions for the larvae, especially for the first instar. Only two of the species showed no clear seasonality and might represent temporal and spatial opportunists. Most striking is the more or less stable population size of the adults of $O$. chrysis. This species has either a much higher longevity in the adult stage or its larval development is independent of the postulated seasonal change in prey abundance.

\section{ACKNOWLEDGEMENTS}

This study was part of a project supported by the German Research Foundation (Deutsche Forschungsgemeinschaft (DFG)) within the project: 'Mechanisms that maintain tropical diversity' ( $\mathrm{Pa}$ 99/15$1,15-2,15-3,15-4)$. The monthly censuses of beetles were done by Francisco P. da Silva. Prof. Dr. David L. Pearson (Arizona State University, Tempe/USA) and Dr. Erik Arndt (Fachhochschule Anhalt, Bernburg/Germany) made valuable comments on the manuscript. PD Dr. W.J. Junk (MPI Plön/Germany) is thanked for logistic support at Manaus.

\section{Literature cited}


Adis, J.; Paarmann, W.; Amdt, E; Amorim, M.A.; Fonseca, C.R.V. da 1998. On occurence, habitat specifity and natural history of adult tiger beetles (Coleoptera: Carabidae, Cicindelinae) near Manaus, Central Amazon, Brazil, and key to the larvae of tiger beetle genera. Acta Amazonica 28(3): 247-272

Amorim, M.A.; Adis, J.; Paarmann W. 1997a. Life cycle adaptations of a diurnal tiger beetle (Coleoptera, Carabidae, Cicindelinae) to conditions on Central Amazonian floodplains. In: Ulrich, H. (ed) Proceedings Int. Symp. on Biodiversity and Systematics in Tropical Ecosystems, Bonn, 1994. Zoologisches Forschungsinstitut und Museum Koening. p. 233-239.

1997b. Ecology and adaptations of the tiger beetle Pentacomia egregia (Chaudoir) (Cicindelinae: Carabidae) to Central Amazonian floodplains. Ecotropica: 3(2): 71-82

Arndt, E.; Paarmann, W.; Adis, J. 1997. Description and key of larval Cicindelidae from Brazil (Coleoptera: Caraboidea). Acta Soc. Zool Bohem. 60: 293-315.

Freitag, R; Barnes, B.L. 1989. Classification of Brazilian species of Cicindela and phylogeny and biogeography of subgenera Brasiella, Gaymara new subgenus, Plectographa and South American species of Cylindera (Coleoptera: Cicindelidae). Quaest. Entom. 25: 241-386.

Linsenmair, K.E. 1990. Tropische Biodiversität: Befunde und offene Probleme. Verh. Dtsch. Zool. Ges. 83: 245-261.

Paarmann, W.; Irmler, U.; Adis, J. 1982. Pentacomia egregia Chaud. (Carabidae, Cicindelinae), a univoltine species in the Amazonian inundation forest. Coleopt. Bull. 36: 183-188.
Pearson, D.L. 1980. Patterns of limiting similarity in tropical forest tiger beetles (Coleoptera: Cicindelidae). Biotropica, 12: 195-204.

Pearson, D.L. 1984. The tiger beetles (Coleoptera: Cicindelidae) of the Tambopata Reserved Zone, Madre de Dios, Perú. Rev. per: Ent., 27: 15-24.

Pearson, D.L. 1988. Biology of tiger beetles. Ann. Rev. Entomol., 33: 123-147

Pearson, D.L.; Huber, R.L. 1995. The tiger beetles of Pakitza, Madre de Dios, Perú: Identification, natural history and a comparison to the Peruvian fauna ( $\mathrm{Co}-$ leoptera: Cicindelidae). Cicindela, 27: 1-28.

Pearson, D.L.; Juliano, S.A. 1991. Mandible length ratio as a mechanism for co-occurrence: evidence from a worldwide comparison of tiger beetle assemblages (Cicindelidae). Oikos, 60: 223-233.

Pearson; D.L.; Knisley, C.B. 1985. Evidence for food as a limiting resource in the life cycle of tiger beetles (Coleoptera: Cicindelidae). Oikos, 45: 161-168.

Pearson, D.L.; Mury, E.J. 1979. Character divergence and convergence among tiger beetles (Coleoptera: Cicindelidae). Ecology, 60: 557-566.

Ribeiro, M. de N.G.; ADIS, J. 1984. Local rainfall variability - a potential bias for bioecological studies in the Central Amazon. Acta Amazonica, 14 (1/2): 159-174.

Ribeiro, M. de N.G.; Villa Nova, N.A. 1979. Estudos climatológicos da Reserva Florestal Ducke, Manaus AM. III. Evapotranspiração. Acta Amazonica, 9: 305-309.

Rodrígues, J.P.; Joly, L.J.; Pearson, D.L. 1994. Los escarabajos tigre (Coleoptera: Cicindelidae) de Venezuela: Su identificacion, distribución e historia natural. Boletin de Entomologia Venezolana. N.S. 9: 55-120. 